\title{
Chapter 19 \\ Ageism and Anti-Ageism in the Legal System: A Review of Key Themes
}

\author{
Israel (Issi) Doron, Ann Numhauser-Henning, Benny Spanier, \\ Nena Georgantzi, and Eugenio Mantovani
}

\subsection{Introduction}

This chapter provides an overview of legal frameworks relevant for addressing the social phenomenon of ageism in Europe. In writing this chapter, we have been interested in how sources ascribable to law and ageing in Europe can grasp ageism, "a process of systematic stereotyping and discrimination against people because they are old" (Butler 1975).

This chapter is one of three others included in this book that are differently related to legal institutions and legal frameworks which are relevant to ageism in Europe. The reason for including three different chapters stems from the need to accommodate the diverse legal regimes and constructions that are available under different European jurisdictions.

This chapter provides a general overview of the inter-relationships between law, ageing and ageism including the presentation of some illustrative examples. It places the overview in the European historical context and discusses specific the-

\section{Doron $(\varangle)$}

The Center for Research and Study of Aging, Department of Gerontology, University of Haifa, Haifa, Israel

e-mail: idoron@univ.haifa.ac.il

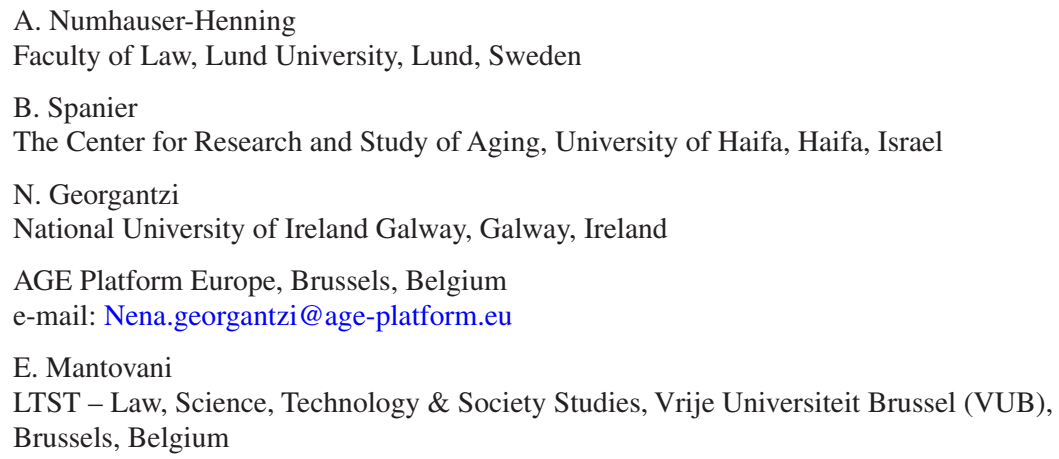


matic cases, such as compulsory retirement and empirical studies regarding the European Court of Human Rights and the Court of Justice of the European Union.

The second chapter (2018; Chap. 20) moves from the general to the specific, focusing on a central European institution, the Council of Europe. Founded in 1949, this regional organization promotes human rights in Europe. This chapter discusses law and ageism through the lens of the Council of Europe's instruments and bodies: the European Social Charter, the jurisprudence of the European Court of Human Rights, and the Council of Europe non-binding "soft-law" means.

The third chapter (2018; Chap. 21) focuses on the European Union. The European Union operates on a legal basis, the EU Treaty of the functioning of the European Union (TFEU), and structures that are autonomous and different from that of the Council of Europe. This chapter broaches ageism under the light of the EU Charter of Fundamental Rights, of the European Union's directives and policies on ageing, and of the case law of Court of Justice of the European Union.

By combining general and more specific legal perspectives, this triad of contributions provides, it is hoped, a resourceful and comprehensive source to understand how ageism and law interact within the European context.

The present chapter is structured as follows: Part One, describes the development of the field of "law and ageing" in Europe from a historic perspective. It detects in the equality provisions, as rooted in international and European human rights law, the main place for the (potential) emancipation of older persons from stereotypes and prejudices. Part Two provides a general overview of ageism and international human rights law. It describes the current tensions surrounding the debates around the need for a new specific international convention for the rights of older persons. Part Three provides specific "case-studies" of the inter-relations between law and ageism: one - focuses on EU law and compulsory retirement; two - focuses on a quantitative analysis of case-law from the European Court of Human Rights (ECoHR) and the Court of Justice of the European Union (CJEU); and three - draws the attention to existing studies regarding the relationships between law and ageism on the micro level, and in specific how law and ageism is perceived by lawyers and older clients.

\subsection{Part One - Law and Ageing: A Short History}

Before the early 1970s, the area of legal inquiry that is today referred to as "elder law" or "law and ageing" was virtually unknown in the field of law (Levine 1982; Bogutz 2008). Equally, the study of the relationships and interconnections between law, older persons and/or the ageing process was latent in the debates of social gerontologists (Doron 2009). This state of affairs changed dramatically with the emergence, almost 50 years ago, in the United States, of "law and ageing" as an autonomous field of legal scholarship and practice. The emergence of law and ageing as a field of legal studies and practice in the United States in the early 1970s can be ascribed to three factors: first, the demographic ageing of American population 
and the social changes that this wrought on all fields of life, demanding a social response; second, the awareness on the part of private bar and private lawyers that their clients were growingly older. This has pushed lawyers from different branches of law to "specialise" in the field of elder law. Third, and finally, the academia and the research community at large realised the opportunity and need to explore this new field of law. As an outcome of the combination of these three factors, the field of "elder law" has become recognised as a unique field and expertise in law, in the United States in particular, with its specific law journals, professional bodies, as well as new programs and classes have been established within law schools.

Unlike the United States, continental Europe has been much slower in developing and recognising elder law as a specific field of knowledge within the legal profession and academic circles (Evrard and Lacour 2012). One could argue - only in passing, as there is no place to hold this discussion here (Doron 2009) - that this is due to a combination of the history of the notion of citizenship in Europe, with the continental-law tradition of universalism which makes it difficult to justify the "separation" of the rights of older persons from the general law on human rights. However, from the beginning of the 1990s, a growing body of research has emerged on the rights of older persons (Doron 2009; Soden and Doron 2012). Today, the Norma Elder Law Research Environment, developed with the Norma Research Programme at Lund University, Sweden, is arguably the most well-established example of a legal laboratory in Europe that concentrates on the legal status and position of older persons within legal systems and in society (Norma Research Programme 1996).

Social gerontology was also slow in recognizing the importance of the interconnections between law and ageing. In short, social gerontologists became interested in elder law when they recongised that the law, for instance, on access to training, to health, is also part of our culture and understanding of social ageing experiences (Levine 1982). Since then, a growing body of inter-disciplinary projects has sought to bring together lawyers and social-gerontologists. These efforts have led to new approaches and outcomes, such as what is called "jurisprudential gerontology" or "geriatric jurisprudence" (Doron 2006). These outcomes, while reflecting a very much "work in progress" situation, testifies to the increasing consensus among scholars that, on the one hand, the law cannot ignore the ageing of human society and that, on the other hand, social gerontology, cannot ignore the legal impact and inter-connections associated with being old. This means that, when exploring and trying to better understand social phenomena such as ageism one should also look at and into the ways law incorporates, supports, or attempts to oppose it.

\subsection{Part Two Ageism and International Human Rights}

A key theme at the intersection of law, ageing, and ageism in Europe concerns the human rights status of older persons. The aim of this descriptive analysis is to gain a better understanding of how human rights law seizes ageism. A starting point for 
discussing ageism from a positive, international human rights law perspective is arguably the Universal Declaration of Human Rights (UDHR), adopted by the United Nations (UN) General Assembly in 1948. The Universal Declaration of Human Rights recognises that all humans are born free and equal in dignity and rights (art. 1). "Everyone", continues article 2, is entitled to all the rights and freedoms set forth in it, "without distinction of any kind, such as race, colour, sex, language, religion, political or other opinion, national or social origin, property, birth or other status." While arguably, being "old" can certainly be covered under "other status" - it is interesting to note that "age" does not specifically appear in this article.

Moreover, ageism can act as a barrier to the enjoyment of the inherent entitlement of all human beings to human rights, such as the right to adequate standard of living, to health, to access justice, to live free from violence and abuse (OHCHR 2012). The stereotyping and discriminating against individuals or groups on the basis of their age (Butler 1975) may be "under the skin" of social norms and prejudices, but lead to very concrete and overt age discrimination (Chung 2010, p.4; Herring 2009, p.12). Employers, for instance, who struggle with their own sense of ageing, may more easily make discriminatory choices in hiring older persons.

In the international human rights system, there is no general legal instrument to dispel prejudices against older people. However, starting from the 1990s and with increasing momentum in the last decade, human rights law actors have begun to study how human rights can combat ageism. In 1996, General Comment (n. 6) of the Committee supervising, the Covenant on Economic Social and Cultural rights (IESCR) had clarified that the list of forbidden grounds of discrimination contained in the core human rights treaties must be interpreted as including age (CESCR 1996); 13 years later, in 2009, the same committee recognised age as a "prohibited ground of discrimination in several contexts", e.g., against unemployed older persons in finding work, in access to training and retraining, and on discrimination in access to universal old age pension due to place of residence" (our italics, CESCR 2009). In 1989, a different UN body, the UN Human Rights Committee, the body that monitors and receives complaints under the 1966 International Covenant on Civil and Political Rights (ICCPR), clarified in General comment No. 18 that the non-discrimination clause extends to any pieces of legislation adopted by a State party. While not mentioning age, the comment indicates that states adopting laws providing, directly or indirectly, for distinctions on the basis of age can also come under scrutiny of nondiscrimination. Under other UN Conventions, the Committee supervising the convention on the Elimination of all forms of Discrimination against Women (CEDAW) recognized ageism as a human rights issue in its general recommendation no. 27 when it reminded that States 'have an obligation to eliminate negative stereotyping and modify social and cultural patterns of conduct that are prejudicial and harmful to older women' (CEDAW 2010, para 36). One year later, in 2011, the UN warned against the "ingrained stigma and discrimination- the ageism- which many older people are subjected to" in access to primary care and health prevention (Grover 2011; UN Human Rights Council 2011). The UN Independent Expert on the Enjoyment of All Human Rights by Older Persons was appointed in 2014. In her 2015 report, she pointed out how "Ageist attitudes still persist throughout the world, 
leading to discriminatory practices towards older persons, including in care settings. Age-based discrimination generates a lack of self-esteem and disempowerment, and undermines an older person's perception of autonomy" (Kornfeld-Matte 2015).

Arguments like these have been put forth, more recently, to advocate for a more affirmative specification of a human rights law (Mégret 2011; Doron and Apter 2010; De Hert and Mantovani 2011; Seanad Public Consultation Committee 2012). The failure of the existing mechanisms to adequately address ageism at the different levels and spheres of social life is one of the arguments of the proponents for a new Convention, which include primarily Latin American and Caribbean States (ECLAC 2007), more recently joined by African and Asian countries. In this debate European States have remained skeptical (Helpage International 2013).

\subsection{Part Three: The Real Context of Law and Ageism - Three Examples}

After providing a broad overview of elder law in general, and the international context of human rights law and its relevance to older persons, this part offers three specific examples which are representative of the diverse and complex ways in which law and ageism interact.

\subsubsection{Example 1: Ageism, Non-discrimination and Employment Law in the EU}

This section will present a more specific legal framework regarding age discrimination under the European Union law. From the legal science point of view there is a special and close connection between ageism and non-discrimination regulation. The reason for choosing the example of "discrimination" - or discriminatory behavior - is that it is an integral part of most definitions of ageism (Iversen et al. 2009). Moreover, non-discrimination regulations are important tools to come to terms with ageism.

In general, equal treatment and non-discrimination regulation play a central role in today's legislation. As noted earlier, there is yet no international convention proper on older persons' rights in general or against discrimination on the grounds of (old) age more specifically. However, the right not to be discriminated against on the grounds of age has been increasingly constitutionalized in the last decades (O'Cinneide 2015). O'Cinneide delineates how national apex courts, despite the uncertain status of age discrimination as such in constitutional and international human rights law, to a certain extent have been willing to review the degree to which age-based distinctions stand up to constitutional requirements regarding equal treatment and non-discrimination. Already in 1967, age joined sex and race as a ground 
for discrimination in the United States, and age as a prohibited ground has subsequently appeared in the constitutions of countries such as Canada, South Africa and Finland. In the EU, the Amsterdam Treaty of 1997 (now Article 19 of the Treaty on the Functioning of the European Union -TFEU) provided new competences for EU institutions to take measures against discrimination inter alia on the grounds of age. In its Article 2,1 the EU Charter of Fundamental Rights (which after the Lisbon Treaty became part of the primary EU law) contains a ban on discrimination concerning, among other grounds, age (Meenan 2007). To date, EU law prohibits discrimination on the ground of age only in the field of employment. Things may change as the Council of the EU, leveraging on article 21 of the Charter of Fundamental Rights and article 19 of the Treaty on the Functioning of the European Union, may adopt a directive on 'horizontal' age discrimination that will expand the age discrimination clause to new areas (European Commission proposal European Commission Proposal for a Council Directive 2008).

\subsubsection{Age Discrimination in Employment Under EU Law}

In the EU, after the Amsterdam Treaty of 1997, the Council adopted Directive 2000/78/EC, the Employment Equality Directive, a regulation which provoked interest in the topic of age discrimination in employment among European scholars (Fredman and Spencer 2003; Meenan 2007; Sargeant 2008; Schlachter 2010; Hendrickx 2013; Numhauser-Henning and Rönnmar 2015). The Directive includes a non-discrimination clause on the ground of age among other grounds but also admits - in its article 6 - the possibility to justify direct age discrimination. In contrast to the US, where the Age Discrimination in Employment Act (ADEA) of 1967 is purposefully targeting older workers, the Directive 2000/78/EC is not specific to old age, but it instead covers discrimination against all ages (Tobler 2015).

However, as the Directive targets the labour market, it is relevant for persons who are approaching their post-employment years or who are being just above 50 years of age and older (Julén Votinius 2016). As anticipated, a key provision is article 6, which provides that differences of treatment on the ground of age "shall not constitute discrimination, if, within the context of national law, they are objectively and reasonably justified by a legitimate aim, including legitimate employment policy, labour market, and vocational training objectives, and if the means of achieving that aim are appropriate and necessary.' In essence, the directive proscribes direct age discrimination which is not justified by a legitimate aim (article 6.1. provides a non-exhaustive list of examples) and which is attained by means that are disproportionate to the aim.

Being open to justification, one important theme in the literature is whether age discrimination in itself is more acceptable than other forms of discrimination. Agebased distinctions are not linked to historically embedded patterns of group subordination and thus, do not have a negative impact upon human dignity to the same degree as do distinctions based on archetypical non-discrimination grounds such as gender and race (O'Cinneide 2015, p 14). Dagmar Schiek, apart from the 'common 
rationale' of discrimination law related to 'ascribed otherness,' also distinguishes policy aims related to both the sustainability of future pension claims and the ban's dysfunctional nature in relation to hitherto established labour law (Schiek 2015). These rationales have also been discussed in terms of a 'double bind' associated with the age discrimination ban (Hendrickx 2013; Numhauser-Henning 2015; Schiek 2011). They include on the one hand, the 'collective' interest approach in terms of social and economic policy planning (such as compulsory retirement but also active ageing strategies); and on the other hand, the 'individual' interest approach such as the pursuit of freedom of choice and dignity at the individual level.

Macnicol draws attention to the application of Art. 6.1 as an accepted expression of statistical discrimination. On the one hand, writes Macnicol (Macnicol 2006, p.11), age as a proxy 'lumps together a wide range of abilities.' This, he suggests, is manifestly unfair, given the great heterogeneity that exists amongst older persons. On the other hand, 'age proxies can also be seen as cheap, convenient and quick methods of decision-making, based upon judgements about working capacity which are fundamentally correct in the aggregate, even if their use may involve individual cases of injustice' (Macnicol 2006, p.11).

This weaker format of the EU ban on age discrimination is an important reason why age discrimination has been the subject of so many Court of Justice of the European Union decisions. The balance to be struck between the individual approach and the collective approach is achieved precisely in the case law of the Court of Justice of the European Union and here is where the compatibility of age-based distinctions in national law has been brought to test. In the case Mangold (CJEU, C-144/04), the Court of Justice of the European Union ruled that 'the principle of non-discrimination on the grounds of age must be regarded as a general principle of Community law' (paragraph 75). The conceptualization of equality on the ground of age as a general principle of EU law has been qualified in subsequent decisions, such as Kücükdeveci (CJEU, C-555/07) and Prigge (CJEU, C-447/09).

Overall, it is possible to say that the Court has remained stable on the position taken in Mangold, acknowledging the existence of a general principle of nondiscrimination on grounds of age in European Union law. As for the content of the substance of the discrimination test, however, O'Cinneide's comment is that the court has been prone to apply 'a light rationality' test accepting justifications such as policy promoting intergenerational employment, whenever 'they can be shown to be rationally linked to the achievements of a legitimate aim' (O'Cinneide 2015, p 59). Similarly, Meenan concludes her analysis of the case law of the Court of Justice of the European Union on age discrimination suggesting that, in practice, age discrimination in itself has proven a more acceptable ground than other forms of discrimination (Meenan 2007). For others, the court has applied a lenient proportionality test in relation to issues such as compulsory retirement, and a somewhat stricter test in cases involving pension reforms and pension-related benefits (Schlachter 2011; Kilpatrick 2011). Fudge, who distinguishes three different sets of proportionality tests, argues that the strictest test applies to occupational requirements (Fudge 2016). 
A ban on age discrimination is thus per se an example of 'anti-ageist' legislation. What makes the EU ban double-edged is the scope for justification of direct discrimination. The 'anti-ageist' effect of the ban relies on the interpretation of this scope according to Article 6.1 in the Employment Equality Directive. At the domestic level, ageism in other fields (e.g. finances) has not been put to the test in case law to any greater extent, despite empirical studies revealing its existence (Meenan 2007, p 282). However, non-discrimination regulation is typically 'elitist' in character - meritocracy is generally speaking the hidden norm - and truly anti-ageist practices can be said to often require a working life adapted to older workers' special needs, such as flexible work arrangements and so on (Ilmarinen 2001; NumhauserHenning 2013). In contrast with disability discrimination, accommodation is not an integrated requirement concerning age discrimination. If and when positive action elements exist, these are often related to age as a traditional stratifier in labour law and standard employment contract perceptions - be it seniority rules in redundancy situations or seniority wage-setting (Foubert et al. 2013; Numhauser-Henning 2015). Age-related active measures are known to exist, however, by means of both legislation and collective bargaining (ter Haar and Rönnmar 2014; Rönnmar 2015).

\subsubsection{The Case of Compulsory Retirement}

One could ask how is it possible that what appears to be age discrimination in employment may be legitimate and proportional decision-making in matters of personnel management. An important example of the double bind conundrum is compulsory retirement.

Pension system sustainability is one of the great challenges in relation to an ageing population for EU Member States. Public standard pension schemes were mainly developed during the twentieth century as a response to standard employment and traditional labour law (Freedland 2013; Strauss 2013). In the case law of the European Union Court of Justice, e.g., Palacios de la Villa (CJEU, C-411/05), Age Concern England (CJEU, C-388/07), Rosenbladt (CJEU, C-45/09), and Hörnfeldt (CJEU, C-141/11), the question that arises is whether acceptance of continued compulsory retirement is justified under article 6.1 of the Employment Equality Directive or whether the age discrimination ban instead should be uphold. In the case Hörnfeldt, the Swedish government argued for yes, 'the 67-year rule [for compulsory retirement]', says Sweden 'seeks, firstly, to avoid termination of employment contracts in situations which are humiliating for workers by reason of their advanced age'. And added that 'the age-limit reflects the political and social consensus which has long prevailed between the social partners' (Hörnfeldt, paragraphs 26 and 27). The court limited itself to observe that 'automatic termination of the employment contracts of employees [...] has, for a long time, been a feature of employment law in many Member States and is widely used in employment relationships. It is a mechanism which is based on the balance to be struck between political, economic, social, demographic and/or budgetary considerations and the choice to be made between prolonging people's working lives or, conversely, providing for 
early retirement' (Hörnfeldt, paragraph 28 - citingthe Rosenbladt case [CJEU, C-45/09], paragraph 44) where it was first formulated).]

As indicated above, a good number of scholarly articles have concentrated on the proportionality test (i.e. a key legal principle which limits the Court's intervention) applied and its strictness in comparison with other cases. Another set of articles has concentrated on understanding the why (e.g. the reasons and rationale) of this continued practice of compulsory retirement (Schiek 2011; Suk 2012; NumhauserHenning 2015). The Court of Justice of the EU has accepted the following as legitimate aims: intergenerational fairness in terms of access to employment, prevention of humiliating forms of employment termination, and a reasonable balance between labour-market and budgetary concerns. The existence of a right to a pension has also played a significant role in the continued acceptance of compulsory retirement, though rather at a system level than in the individual case (CJEU, C-411/05 and C-141/11). The Court of Justice of the EU's acceptance on grounds of intergenerational fairness contrasts with economic research (of both a theoretical and empirical nature), which emphasizes the 'lump of labour fallacy,' and opposes propositions that compulsory (or premature) retirement schemes will help to combat youth unemployment or that older workers crowd younger workers out of the labour market (Dewhurst 2013). Behind the humiliation argument lies the fact that in upholding the ban against age discrimination, dismissal cases would be all about ability - or rather lack thereof. An extrapolation of this line of arguments is the risk of weakening European-style employment protection altogether - and, moreover, furthering flexible employment (Numhauser-Henning 2013, 2015). This line of argument can be said to be confirmed by the UK's experience after abolishing compulsory retirement as the general rule (Manfredi and Vickers 2016). In the UK, the continued opening for an 'Employer-justified Retirement Age' is an issue of concern - not least in a university context (Barnard and Deakin 2015; Dewhurst 2016). In an overall perspective - and despite the Court of Justice of the EU's acceptance hitherto - the practice of compulsory retirement is no doubt losing ground in the EU Member States.

\subsubsection{Example 2: Law, Ageism, and Courts}

Courts, and case-law, play an important role in the development of jurisprudence in the field of ageism and elder law. However, and despite the growing interest and awareness to ageing and ageism within the European legal system and within international human rights bodies, not much empirical research has been conducted in this field. While specific cases - as presented in the previous sections- serve as precedents of legal policy, questions still remain regarding the broader legal work done by courts when it comes to ageism or older persons. In this section, two empirical studies regarding case law and ageism will be presented: The first, from the European Court of Human Rights; and the second from the Court of Justice of the European Union. 
The importance of empirical studies of court rulings is underlined in legal theory, which sees courts as social institutions, playing an important role as a tool for social change. Both in North America and Europe, courts have been used as strategic tools by individuals or human rights organization in order to promote the rights of minority or excluded social groups. It is against this backdrop and from this symbolic perspective that both the European Court of Human Rights as well as the Court of Justice of the European Union are analysed in the following paragraphs.

\subsubsection{Empirical Study of the European Court of Human Rights}

The European Convention on Human Rights does not explicitly address the rights of older persons as such. This is in-and-by itself an interesting point: older persons, as a unique social group - are "invisible" in Europe's key human rights instrument. To the extent that older people are to enjoy human rights, they need to find "auspices" within the context of the convention's general articles. It is not surprising, then, that to date the sphere of elder rights has practically not been studied at all within the context of the European Court of Human Rights. Until recently, even the Court itself did not address elder rights as a unique legal subject. This changed only in the last years, when the Court published a document in which it reviewed, in an unsystematic manner, the main judgments dealing with the subject. ${ }^{1}$

A recent study by Spanier et al. (2013), on which the following lines are based, offers a general, descriptive investigation of the extent to which the rights of older persons are discussed in this Court. The methodology of the research included an empirical analysis of the case law of the European Court of Human Rights, retrieving varied background data about judgments involving older persons from the Court's website (HUDOC). ${ }^{2}$ Due to limited time and resources, a stratified random sampling of 226 judgments were analyzed for this study. In general, the number of judgments delivered to persons aged 60 or above, out of all judgments delivered by the Court in the same years, are represented in percentage in the following graph (Fig. 19.1).

The period of time under scrutiny corresponds to the years following the entry into force of protocol 11 (1998), which introduced a reinforced judicial mechanism, allowing any individual claiming to be the victim of a violation of the Convention to bring a complaint directly to the European Court of Human Rights. After an initial stage in which an increase in applications by older persons was registered, in line with the general increase that followed the entry into force of Protocol 11, the relative rate of older persons' applications stabilized; an average of $11.9 \%$ of judgments were delivered to older persons throughout the period 2000-2010.

\footnotetext{
${ }^{1}$ Elderly People and the European Convention on Human Rights, available at: http://www.echr. coe.int/Documents/FS_Elderly_ENG.pdf (Last visited November 2014).

${ }^{2}$ Available at:

http://www.hudoc.echr.coe.int/sites/eng/Pages/search.aspx\#\{ “documentcollectionid2":["GRA NDCHAMBER","CHAMBER"]\} (Last visited November 2014).
} 


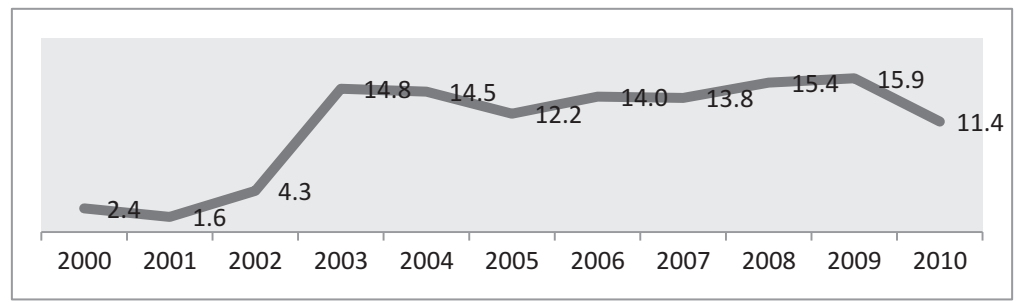

Source: Spanier, Doron, \& Milman-Sivan, 2013: pg. 411.

Fig. 19.1 Percentage of judgments given to older persons in relation to all the judgments made in each year (Source: Spanier et al. (2013): pg. 411)

These findings can be interpreted in different ways. Considering that older persons are relatively poor and potentially more disabled, accessibility to the legal systems is more complex for this than for other age groups. Hence, these data can be interpreted positively, in spite of difficulties, older persons do reach the European Court of Human Rights. On the other hand, one must recall that Europe has the largest older population in the world (160 million), about $20 \%$ of the entire population of Europe (approximately 800 million) (UN Secretary General 2009). Hence, the percentage of judgments dealing with older persons in Europe is still lower than the relative percentage of older adults in the population.

In a second phase, the study on older persons and the European Court of Human Rights looked beyond the mere number of applications into the substantial legal issues raised by older persons. For an application to be accepted to the Court, the applicant must prove that the act in question violates one (or more) of the articles of the Convention. In this study, we examined the main provisions mobilized in Court in older persons' applications. The provisions that were mostly mobilized in applications lodged by older persons were:

First Type of Cause: Article 6, Right to a Fair Trial The largest number of cases brought to the Court by older persons activate article 6 . The Court has heard under this article cases in which the reasonable time to obtain justice and redress, the accessibility to legal systems, and the failure to enforce judicial decisions were at stake. In the case of Romanika v. Poland of 2006 (ECtHR Application no. 53284/99), the applicant, aged 78, took Romania to the Strasbourg court after lamenting the excessive length of the civil proceeding he had been involved in: some 13 years, for the dissolution of a co-ownership. The Court, "having regard to the applicant's age," ruled that it could "not accept the Government's opinion that special diligence was not called for in the present case" (paragraph 62).

Second Type of Cause: Protocol 1, Article 1, Right to the Enjoyment of Possessions this category comprises cases dealing with claims of older persons regarding the right to the enjoyment of possessions. According to the Court's judgment, this is a comprehensive right, including not only property rights, but also the rights to a salary, welfare payments, pension rights (Harris et al. 2009). 


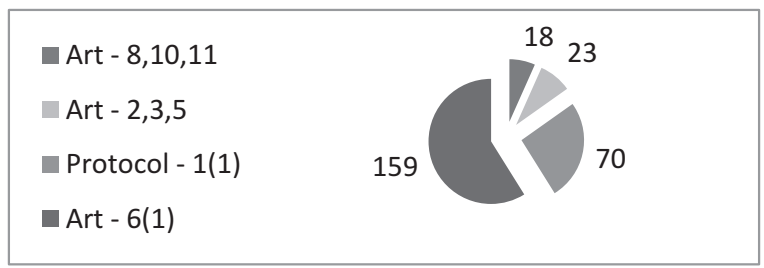

Source: Spanier, Doron, \& Milman-Sivan, 2013: pg. 413.

Fig. 19.2 Distribution of number of cases according to main articles (Source: Spanier et al. (2013): pg. 413) (In many cases, Section 6(1) is only part of the application. The applications join it onto other sections, which, they believe, were violated according to the Convention. It should be noted that, because some cases overlap, the number of judgments described in the table is larger than the sample number of 226 . Therefore, the numbers stands for the cases and not percentages)

Third Type of Cause: Articles 2, 3, 5, Breach of the Right to Life and Liberty The sections in this type of cause usually deal with loss of life (Frederic 2007), caused by the state (Gandaloyeva v. Russia (2008) ECtHR Application no. 14800/04), or by the police (Ramsahai and others v. The Netherlands (2007) ECtHR Application no. 52391/99). What emerges from this case law is that in some cases older persons are themselves victims of death or damage caused by poor hospital conditions and/or inappropriate treatment, involuntary transfer (article 2), inhuman or degrading punishment or treatment (article 3), deprivation of liberty or confinement (article 5) (Fig. 19.2).

\subsubsection{An Empirical Study of the Court of Justice of the European Union}

Similar to the previous study, the research on the Court of Justice of the European Union (CJEU) delves on cases drawn from the court's database, obtained by typing search keywords (e.g. elderly, senior, old etc.), and by screening for cases relevant for the rights of older persons (for a detailed description of the methodology see Doron 2013). As a result, 123 cases were analyzed, covering a period of time from 1994 to 2009.

Almost half the cases (58/47.2\%) pertained to "Social Policy" issues. e.g. calculation of the pension rights (39\%) and equal treatment for men and women (31.7\%, while the two other major legal areas were free movement of persons (29/23.6\%) and social security for migrant workers $(26 / 21.1 \%)$. Only very few elder rights cases involved issues like Competition ( 3 cases), or Principles of Community Law (1 case). The vast majority of cases involved pensions: either state funded pensions (61/49.6\%) or employer-based occupational pensions (36/29.3\%). The rest of the cases were mostly about age discrimination, mandatory retirement or attendance/home care (all of them 6 cases each). There were only 2 cases involving health care issues, and one case involving the regulation of nursing homes. Overall, a "typical" elder rights' case discussed under the Court of Justice of the EU is likely to be dealing with pensions' rights legal issues around its calculation or gender equality in pension treatment. 
On the escort of this statistics, one could suggest, on the one hand, that the amount of elder rights' cases brought before the Court of Justice of the EU is very low compared to the overall case load (more than 6000 throughout the relevant preiod). When they arrive at the Court of Justice of the EU, the focus is around economic issues (pensions) or discrimination in treatment on the ground of sex Major legal issues in the field of elder rights such as patients' rights, health-care, institutional or community-based long term care, housing or employment - are almost non-existent.

On the other hand, within these limited numbers of cases and narrow scope of legal decisions, the outcomes are encouraging. In the majority of the cases, the court rules in favor of older persons. It seems that there is significant awareness for the illegality of sex-discrimination in old age and of the illegality of governments' attempts to hinder the pension rights of older Europeans. In the context of specific countries, such as Germany or Belgium, there is a strong awareness and usage of local courts to the Court of Justice of the EU role.

\subsubsection{Example 3: Ageism, Lawyers and Older Clients}

Our final example is focused on empirical studies regarding the ageist (or antiageist) experiences of lawyers, judges, and older clients. In general, it could be stated that in Europe, there is a very small and limited body of direct empirical research on ageism within the legal system (e.g. lawyers, judges) or from the older persons' perspectives on the legal system. In Israel, several small scale studies have been conducted in these fields. One example can be found in a small scale quantitative study measuring ageism among lawyers (Untzik-Heilbrun and Or-Chen 2014). This study found that while their general knowledge on aging (using PFoAQ) was low, the level of ageist attitudes of lawyers in Israel (based on a convenience sample of 225 Israeli lawyers) was better (less-ageist) compared with Israeli professionals in the medical fields (e.g. nurses), but worse (more-ageist) compared with Israeli travel-agents.

Another example can be found in an Israeli case-study analysis regarding the narrative construction of old age in an Israeli case involving the legality of nursing home contract (Doron 2012). This study found that one can find in the rhetoric of the courts a combination of both stereotypical negative depiction of old age, as well as a non-ageist, an emancipatory and empowering picture of older persons as autonomous and independent agents. Finally, another small scale study in Israel looked into the experience and attitudes of older persons with regards to the legal system (Segal et al. 2014). This quantitative study (based on a convenience sample of 219 older Israeli - 60 years old and above) found that in general, the attitudes of older persons towards the Isreali legal system were negative. However, in a qualitative study regarding the accessibility of the courts to the older population in Israel, the participants described how judges gave them special respect once in the court room due to their old age (Ben-Eliezer and Doron 2011). 


\subsection{Concluding Remarks}

This chapter has provided an overview of the field of law, ageing and ageism; a general description of existing international norms in the field of ageism; and three specific examples on how law and ageism inter-relate. This chapter joins two other chapters in this book (2018, Chaps. 20-21) which together provide a descriptive analysis of how European legal frameworks are relevant for older persons in general, and how they can potentially assist in combating ageism in particular.

This general descriptive picture provides key considerations and recommendations for future research. It seems that overall there is relatively limited awareness to ageism and to "older persons" as a unique and distinguished social group within European jurisprudence. Therefore, there is a need for more research and debate on the impact that "elder-specific" mechanisms or initiatives, such as the complaints instigated by association and heard by the European Social Committee, could have on the perception of ageism and discrimination on the ground of age. Moreover, there is a lack of empirical research about how national courts of law respond to the problem of ageism. The methodology and the research offered in this chapter on the case law of the European Court of Human Rights could be replicated in the context of the Council of Europe's European Social Charter as well as national constitutional courts. Empirical research in the field of law, ageing and ageism could also be more targeted and, for instance, embrace real life experiences. In this connection, one notes an almost total a lack of empirical studies regarding the attitudes of lawyers towards older clients, and regarding experiences of older clients in their encounter with lawyers and with the legal system. More empirical research is needed in this field in order to better understand the inter-connection between law and ageism and to allow for the development of a theoretical framework that will explain this reality.

\section{References}

Barnard, C., \& Deakin, S. (2015). Age discrimination and labour law in the UK: Managing ageing. In A. Numhauser-Henning \& M. Rönnmar (Eds.), Age discrimination and labour law, Comparative and conceptual perspectives in the EU and beyond. Alphen aan den Rijn: Wolters Kluwer.

Ben-Eliezer, A., \& Doron, I. (2011). The meaning of accessibility to the courts by older persons. Gerontology, 38(1), 71-89 [Hebrew].

Bogutz, A. D. (2008). Elder law: A personal perspective. In I. Doron (Ed.), Theories on law and ageing. The jurisprudence of Elder Law (pp. 1-9). Berlin Heidelberg: Springer.

Butler, R. N. (1975). Why survive?: Being old in America. New York: Harper and Row.

Chung, C. (2010). The necessity of a human rights approach and effective United Nations mechanism for the human rights of the older person.

Committee on Economic, Social and Cultural Rights (CESCR). (1996). General Comment No. 6: The economic, social and cultural rights of older persons.

Committee on Economic, Social and Cultural Rights (CESCR). (2009). General Comment No. 20: Non-discrimination in economic, social and cultural rights. 
Committee on the Elimination of Discrimination Against Women (CEDAW). (2010). General recommendation No. 27 on older women and protection of their human rights.

De Hert, P., \& Mantovani, E. (2011). Specific human rights for older persons? European Human Rights Law Review, 4, 398-418.

Dewhurst, E. (2013). Intergenerational balance, mandatory retirement and age discrimination in Europe: How can the ECJ better support national courts in finding a balance between generations. Common Market Law Review, 50, 1333.

Dewhurst, E. (2016). Proportionality assessments of mandatory retirement measures: Uncovering guidance for national courts in age discrimination cases. Industrial Law Journal, 45(1), 60-88.

Doron, I. (2006). Elder law: Current issues and future frontiers. European Journal of Ageing, 3(1), $60-66$.

Doron, I. (2009). Theories on law and ageing. The jurisprudence of Elder Law. Berlin/Heidelberg: Springer.

Doron, I. (2012). A Judicial Rashomon: On ageism and narrative justice. Journal of Cross-Cultural Gerontology, 27(1), 17-28.

Doron, I. (2013). Older Europeans and the European Court of Justice. Age \& Ageing, 42, 604-608.

Doron, I., \& Apter, I. (2010). International rights of older persons: What difference would a new convention make to lives of older people? Marquette Elder's Advisor, 11(2).

European Commission Proposal for a Council Directive on implementing the principle of equal treatment between persons irrespective of religion or belief, disability, age or secual oientation, COM (2008) 426 final.

Evrard, A., \& Lacour, C. (2012). A European approach to developing the field of law and ageing. In A. Soden \& I. Doron (Eds.), Beyond Elder Law (pp. 149-173). New York: Springer.

Foubert, P., et al. (2013). An EU perspective on age as a distinguishing criterion for collective dismissal: The case of Belgium and the Netherlands. The International Journal of Comparative Labour Law and Industrial Relations, 29(4), 415-432.

Frederic, E. (2007). The length of civil and criminal proceedings in the case-law of the European Court of 525 Human Rights. Strasbourg: Council of Europe Publishing.

Fredman, S., \& Spencer, S. (2003). Age as an equality issue. Oxford: Hart Publishing.

Freedland, M. (2013). Burying Caesar: What was the standard employment contract? In K. Stone $\&$ H. Arthurs (Eds.), Tehtinking workplace regulation: Beyond the standard contract of employment. New York: Russell Sage Foundation.

Fudge, J. (2016). Dignity, disadvantage and age: Putting constitutional fundamental rights to work for older workers. In A. Numhauser-Hennning(Ed.), Elder law: Evolving European perspectives. Cheltenham: Elgar Publishing. (forthcoming).

Georgantzi, N. (2018). The European union's approach towards ageism. In L. Ayalon \& C. TeschRömer (Eds.), Contemporary perspectives on ageism: Vol. 19. International perspectives on aging (pp. 341-368). Berlin: Springer.

Grover, A. (2011). Thematic study on the realization of the right to health of older persons by the Special Rapporteur on the right of everyone to the enjoyment of the highest attainable standard of physical and mental health.

Harris D. J., O'Boyle M., Bates E. P., \& Buckley C. M.. 2009. Harris, O'Boyle \& Warbric Law of the European convention on human rights (2nd ed.).

Helpage International. (2013). Strengthening the rights of older people worldwide. Osnabrück: Building greater European support.

Hendrickx (Ed.). (2013). Active ageing and labour law, contributions in honour of Professor Roger Blanpain. Cambridge: Intersentia.

Herring, J. (2009). Older people in law and society. Oxford: Oxford University Press.

Ilmarinen, J. (2001). Ageing workers in the European Union - Status and promotion of work ability, employability and employment. Helsinki: Finnish Institute of Occupationalo health, Ministry of Scoial Affiars and Helath, Ministry of Labour.

Iversen, T. N., et al. (2009). A conceptual analysis of ageism. Nordic Psychology, 61(3), 4.

Julén Votinius, J. (2016). Intersectionality as a tool for analysing age and gender in labour law. In S. Manfredi \& L. Vickers (Eds.), Challenges of active ageing. London: Palgrave Macmillan. 
Kilpatrick, C. (2011, September). The court of justice and labour law in 2010: A new EU discrimination law architecture. Industrial Law Journal, 40(3), 280-301.

Kornfeld-Matte, R. (2015). Autonomy and care of older persons - Report of the independent expert on the enjoyment of all human rights by older persons.

Levine, M. L. (1982). Introduction: The frame of nature, gerontology, and law. Southern California Law Review, 56(1), 261-228.

Macnicol, J. (2006). Age discrimination, an historical and contemporary analysis. Cambridge: Cambridge University Press.

Manfredi, S., \& Vickers, L. (Eds.). (2016). Challenges of active ageing. London: Palgrave Macmillan.

Meenan, H. (2007). Reflecting on age discrimination and rights of the elderly in the European Union and the council of Europe. Maastricht Journal of European and Comparative Law, 14, 39.

Mégret, F. (2011). The human rights of older persons: A growing challenge. Human Rights Law Review, 11(1), 37.

Norma Research Programme. (1996). http://www.law.lu.se/\#!TheNormaResearchProgramme. Accessed 15 May 2016.

Mikołajczyk, B. (2018). The council of europe's approach towards ageism. In L. Ayalon \& C. Tesch-Römer (Eds.), Contemporary perspectives on ageism: Vol. 19. International perspectives on aging (pp. 321-339). Berlin: Springer.

Numhauser-Henning, A. (2013). Labour law in a greying labour market - In need of a reconceptualisation on work and pension norms. The position of older workers in labour law. European labour Law Journal, 4(2), 84.

Numhauser-Henning, A. (2015). Labour law, pension norms and the EU ban on age discrimination: Towards ultimate flexibilization? In A. Numhauser-Henning \& M. Rönnmar (Eds.), Age discrimination and labour law, Comparative and conceptual perspectives in the EU and beyond. Alphen aan den Rijn: Wolters Kluwer.

Numhauser-Henning, A., \& Rönnmar, M. (Eds.). (2015). Age discrimination and labour law, Comparative and conceptual perspectives in the EU and beyond. Alphen aan den Rijn: Wolters Kluwer.

O'Cinneide, C. (2015). Constitutional and fundamental rights aspects of age discrimination. In A. Numhauser-Henning \& M. Rönnmar (Eds.), Age discrimination and labour law, Comparative and conceptual perspectives in the EU and beyond. Alphen aan den Rijn: Wolters Kluwer.

Office of the High Commissioner for Human Rights (OHCHR). (2012). Normative standards in international human rights law in relation to older persons - Analytical outcome paper.

Rönnmar, M. (2015). Age discrimination and labour law: A comparative analysis. In R. NumhauerHenning (Ed.), Age discrimination and labour law, Comparative and conceptual perspectives in the EU and beyond. Alphen aan den Rijn: Wolters Kluwer.

Sargeant, M. (2008). The law on age discrimination in the EU. Alphen aan den Rijn: Kluwer Law International.

Schiek, D. (2011). Age discrimination before the ECJ - Conceptual and theoretical issues. Common Market Law Review, 48, 777.

Schiek, D. (2015). Proportionality in age discrimination cases - Towards a model suitable for socially embedded rights. In A. Numhauser-Henning \& M. Rönnmar (Eds.), Age discrimination and labour law, Comparative and conceptual perspectives in the EU and beyond. Alphen aan den Rijn: Wolters Kluwer.

Schlachter, M. (Ed.). (2010). The prohibition of age discrimiation in labour relations. Reports to the XVIIIth international congress of comparative law, Nomos.

Schlachter, M. (2011). Mandatory retirement and age discrimination under EU law. IJCLLIR, 27, 287-299.

Seanad Public Consultation Committee. (2012). Report on the rights of older people.

Segal, M., Mor, S., \& Hantman, S. (2014). The attitudes of older persons towards the law and courts in Israel: Accessibility, trust and ageism. Gerontology, 41(3), 51-70 [Hebrew]. 
Soden, A., \& Doron, I. (2012). Beyond elder law: New directions in law and aging. New York: Springer.

Spanier, B., Doron, I., \& Milman-Sivan, F. (2013). Older persons' use of the European court of human rights. Journal of Cross-Cultural Gerontology, 28, 407-420.

Strauss, K. (2013). Equality, faoir mutualisation and the socialisation of risk and reward in European pensions. In N. Countouris \& F. Mark (Eds.), Resocialising Europe in a time of crisis. Cambridge: Cambridge University Press.

Suk, J. (2012). From antidiscrimination to equality: Stereotypes and the life cycle in the United States and Europe. American Journal of Comparative Law, 60, 75.

ter Haar, B \& Rönnmar, M (2014). Intergenerational bargaining, EU age discrimination law and EU policies - An integrated analysis (Report for the project iNGenBar).

Tobler, C. (2015). EU age discrimination law and older and younger workers: Court of justice of the European Union case law developments. In A. Numhauser-Henning \& M. Rönnmar (Eds.), Age discrimination and labour law, Comparative and conceptual perspectives in the EU and beyond. Alphen aan den Rijn: Wolters Kluwer.

UN Economic Commission for Latin America and the Caribbean (ECLAC). (2007). Brasilia declaration.

UN Human Rights Committee. (1989). General Comment No. 18 - Non-discrimination.

UN Human Rights Council. (2011). Panel discussion on the realization of the right to health of older persons. Geneva.

UN Secretary General. (2009). Follow-up to the second world assembly on ageing (A/64/127).

Untzik-Heilbrun, I. Or-Chen, K. (2014). Lawyers' attitudes towards older clients in Israel. Gerontology, 41(3), 31-49 [Hebrew].

Open Access This chapter is licensed under the terms of the Creative Commons Attribution 4.0 International License (http://creativecommons.org/licenses/by/4.0/), which permits use, sharing, adaptation, distribution and reproduction in any medium or format, as long as you give appropriate credit to the original author(s) and the source, provide a link to the Creative Commons license and indicate if changes were made.

The images or other third party material in this chapter are included in the chapter's Creative Commons license, unless indicated otherwise in a credit line to the material. If material is not included in the chapter's Creative Commons license and your intended use is not permitted by statutory regulation or exceeds the permitted use, you will need to obtain permission directly from the copyright holder. 